\title{
Simultaneous Screening for Resistance to Blackeye Cowpea Mosaic Virus and Root-knot Nematode in Southernpea
}

\author{
A.G. Hunter ${ }^{1}$ and O.L. Chambliss ${ }^{2}$ \\ Department of Horticulture, Auburn University, AL 36849
}

\author{
J.C. Williams ${ }^{2}$ \\ Department of Research Data Analysis, Auburn University, AL 36849
}

Additional index words. cowpea, breeding, diseases

\begin{abstract}
Four southernpea (cowpea) [Vigna unguiculata (L.) Walp.] cultivars representing various combinations of resistance and susceptibility to blackeye cowpea mosaic virus (BICMV) and southern root-knot nematode [Meloidogyne incognita (Kofoid and White) Chitwood] were used to determine effectiveness of simultaneous screening of plants for resistance to both pathogens. Plants were inoculated with both pathogens simultaneously, each pathogen separately, or left uninoculated as controls. The resistance classification of the cultivars based on treatments with only one pathogen was not different from that based on the treatment with both pathogens. Virus $\times$ nematode interaction was not a significant source of variation in BICMV symptoms and root-knot nematode galls. Simultaneous screening for both pathogens in southernpeas appears to be a feasible option.
\end{abstract}

Southernpeas are commonly grown in the southeastern U.S. for use as a fresh, frozen or canned vegetable. Two major constraints to growing the crop are its susceptibility to southern root-knot nematode and viruses, especially stunt disease caused by the combined infection of blackeye cowpea mosaic virus (BlCMV) and cucumber mosaic virus (CMV) (Pio-Ribeiro et al., 1978). Resistance to southern root-knot nematode is controlled by a dominant gene (Fery and Dukes, 1980). Two genes, one dominant and the other recessive, confer resistance to BlCMV (Ouattara and Chambliss, 1991; Walker and Chambliss, 1981). The current strategy for preventing $\mathrm{BlCMV} / \mathrm{CMV}$ stunt is to breed for resistance to $\mathrm{BlCMV}$ to preclude the synergistic reaction between BICMV and CMV.

Plant breeders commonly use separate pathogen screening operations when developing new cultivars for resistance to nematodes and viruses. Considerable time could be saved if the same plants can be screened for resistance to multiple pathogens, a method used by potato (Solanum tuberosum L.) breeders to select for resistance to potato virus $\mathrm{Y}$, cyst nematodes [Globodera rostochiensis (Woll.) Behrens and G. pillida (Stone) Behrens], and potato blight [Phytophthora infestans (Mont.) DBy.] (Jellis et al., 1986).

Received for publication 28 Mar. 1996. Accepted for publication 26 July 1996. Alabama Agricultural Experiment Station Publication No. 11-965192. Use of trade names does not imply endorsement of the products named nor criticism of similar ones not named. The cost of publishing this paper was defrayed in part by the payment of page charges. Under postal regulations, this paper therefore must be hereby marked advertisement solely to indicate this fact.

${ }^{1}$ Senior Research Associate.

${ }^{2}$ Emeritus Professor.
Nematode-virus interactions may be direct, such as transmission of viruses by nematodes, or, indirect due to changes caused by a pathogen in a plant's defense mechanism as when the presence of a virus alters nematode development and/or multiplication (Taylor, 1990; Weischer, 1993). Inoculation of cowpeas with CMV and $M$. incognita simultaneously or with CMV 10 days before nematode inoculation reduced root galling by $39 \%$ and $24 \%$, respectively, compared to cowpeas inoculated with $M$. incognita only. When virus inoculum was applied after nematode inoculum, virus concentration was $23 \%$ lower than in plants inoculated with virus only (Goswami et al., 1974). Weischer (1975) detected a reduction in nematode counts in tobacco (Nicotiana tabacum L.) plants inoculated with seven viruses and two nematode species, depending on specific virus/nematode combinations. Watermelon mosaic virus did retard the establishment of $M$.javanica (Treub) Chitwood in Cucurbita pepo L. (Huang and Chu, 1984). Severity of infection with nematode species in an interspecific hybrid sugarcane (Saccharum $\times$ officinarum L.) was related to concentrations of free amino acid levels caused by host plant stress as a result of infection with sugarcane mosaic virus (Showler et al., 1990).

The objective of this experiment was to evaluate the effectiveness of screening for resistance to BlCMV and root-knot nematode simultaneously as compared to screening for each pathogen separately.

\section{Materials and Methods}

Four cultivars were used in this experiment: 'California Blackeye 5', susceptible to BlCMV and resistant to root-knot nematode (Ogle et al., 1987); 'Freezegreen', susceptible to BlCMV (Chambliss, 1979) and root-knot nematode (Chambliss and Hunter, unpublished data); 'Mississippi Silver', resistant to both pathogens (Ogle et al., 1987); and 'Worthmore', resistant to BlCMV (Gay, 1976), but reaction to root-knot nematode is unknown.

Seeds were planted in 72-cell styrofoam flats, one seed per cell $\left(5.1 \mathrm{~cm}^{2} \times 7.6 \mathrm{~cm}\right.$ deep $)$, on 9 June 1993 in a greenhouse at 22/30C (night/day) without day length control. Each seed was inoculated with 2,000 eggs of $M$. incognita Race 3 that had been extracted from 'Flora-Dade' tomato (Lycopersicon esculentum Mill.) roots using the procedure described by Hussey and Barker (1973). One week later, seedlings were inoculated with BlCMV provided by Richard O. Hampton, Dept. of Botany and Plant Pathology, Oregon State University, Corvallis. Virus inoculum was prepared and applied using the procedure of Walker and Chambliss (1981). Leaves were lightly misted with water and shaded to prevent succulent primary leaves from desiccating after inoculation.

A split-plot experimental design was used. Main-plot treatments were combinations of BlCMV and root-knot nematode inoculations: ++ , plants inoculated with both pathogens; + - inoculated with BlCMV but not nematodes; -+ , no BlCMV and inoculated with nematodes; and --, no inoculation with either pathogen as the control. A treatment was applied over an entire flat. The subplots were the four cultivars randomly assigned to 18 contiguous cells in each flat. A randomized complete block was used and each of the four blocks was in a separate greenhouse room to prevent contamination among blocks. Flats were randomly arranged in each block and separated from each other to prevent shading and to lower the chance of within-block contamination. Flats were fertilized with $(3 \mathrm{~g} / \mathrm{L})$ Peters General Purpose fertilizer (20N-9.7P16.6K; W.R. Grace \& Co., Fogelsville, Pa.) to run-off at 3 and 6 weeks after planting to prevent nutrient deficiency symptoms.

Plants were rated for BICMV and root-knot resistance 2 months after seeding. Plants with BlCMV symptoms were rated as positive or negative. Roots were washed and scored for root-knot nematode damage on a 1-5 scale where $1=$ severe galling, more than $75 \%$ of roots galled, and $5=$ no galls. To determine the level of interaction between BlCMV and root-knot nematode, an analysis of variance was performed in SAS (ver. 6.09, SAS Institute, Cary, N.C.) using the average root-knot score and the arcsin transformation of the percentage of plants with BlCMV symptoms as dependent variables. A contrast analysis was done to further examine virus $\times$ nematode interactions within cultivars.

\section{Results and Discussion}

Treatments having only one of the pathogens $(+-$ and -+$)$ confirmed the known resistance or susceptibility of the cultivars to BlCMV and root-knot nematode, indicating the isolates were virulent. When both pathogens were present $(++)$ the resistance classification of the cultivars remained the same. Virus $\times$ nematode interaction was not a sig- 
nificant source of variation in the percentage of BlCMV positive plants $(P>\mathrm{F}=0.161)$ or in the average root-knot score $(P>\mathrm{F}=0.097)$ of the four cultivars studied (Table 1).

In contrast analyses with -+ vs. ++ , average nematode scores were significant in 'California Blackeye 5' $(P>\mathrm{F}=0.001)$ and 'Mississippi Silver' $(P>\mathrm{F}=0.015)$, but represent differences of not more than 0.4 . The only unexpected significant probability level for percentage of BlCMV positive plants was for the +- vs. ++ contrast in 'California Blackeye 5' $(P>\mathrm{F}=0.001)$, but the difference detected was between $95.3 \%$ and $79.9 \%$, respectively.

Though nonsignificant, plants inoculated with both pathogens had slightly less nematode damage than plants inoculated with nematodes alone. This difference was considerably less than the reduction observed by Goswami et al. (1974) with CMV and M. incognita. The presence of a virus in some plants can inhibit the development or reproduction of nematodes (Weischer, 1993). This trend could also be related to the large, unexpected effect of blocks on the variation in nematode score, indicating the need to ensure favorable conditions for nematodes during screening.

These results indicate simultaneous screening for resistance to blackeye cowpea mosaic virus and root-knot nematode could be used by plant breeders to reduce their costs and time required to obtain new southernpea cultivars resistant to both pathogens.

\section{Literature Cited}

Chambliss, O.L. 1979. Freezegreen, a new southernpea for processing. Alabama Agr. Expt. Sta. Cir. 242.

Fery, R.L. and P.D. Dukes. 1980. Inheritance of root-knot resistance in the cowpea [Vigna unguiculata (L.) Walp.]. J. Amer. Soc. Hort. Sci. 105:671-674.

Gay, J.D. 1976. 'Worthmore' southernpea. HortScience 11:621-622.

Goswami, B.K, S. Singh, and V.S. Verma. 1974. Interaction of a mosaic virus with root-knot nematode Meloidogyne incognita in Vigna sinensis. Nematologica 20:366-367.

Huang, S.P. and E.Y. Chu. 1984. Inhibitory effect of watermelon mosaic virus on Meloidogyne

Table 1. Average percentage of plants rated as positive to blackeye cowpea mosaic virus and average root-knot nematode score on southernpeas in simultaneous screening experiment (Auburn, Ala., 1993).

\begin{tabular}{|c|c|c|c|c|}
\hline \multirow[b]{2}{*}{ Cultivar } & \multicolumn{2}{|c|}{ Pathogen treatment ${ }^{2}$} & \multirow{2}{*}{$\begin{array}{c}\text { BlCMV } \\
\text { positive } \\
\text { plants } \\
(\%)\end{array}$} & \multirow{2}{*}{$\begin{array}{c}\text { Nematode } \\
\text { score }^{y}\end{array}$} \\
\hline & Virus & Nematode & & \\
\hline \multirow{4}{*}{ California Blackeye 5} & - & - & 00.0 & 4.8 \\
\hline & - & + & 00.0 & 2.5 \\
\hline & + & - & 95.3 & 4.8 \\
\hline & + & + & 79.9 & 2.9 \\
\hline \multirow[t]{4}{*}{ Freezegreen } & - & - & 00.0 & 4.9 \\
\hline & - & + & 01.5 & 2.3 \\
\hline & + & - & 98.6 & 4.9 \\
\hline & + & + & 94.4 & 2.3 \\
\hline \multirow[t]{4}{*}{ Mississippi Silver } & - & - & 00.0 & 5.0 \\
\hline & - & + & 00.0 & 3.7 \\
\hline & + & - & 00.0 & 4.9 \\
\hline & + & + & 02.8 & 4.1 \\
\hline \multirow[t]{4}{*}{ Worthmore } & - & - & 00.0 & 5.0 \\
\hline & - & + & 00.0 & 3.5 \\
\hline & + & - & 01.6 & 4.9 \\
\hline & + & + & 01.6 & 3.8 \\
\hline \multicolumn{3}{|l|}{ Source } & \multicolumn{2}{|c|}{$P>F$} \\
\hline Reps & & & 0.5207 & 0.0009 \\
\hline Cultivars & & & 0.0001 & 0.0001 \\
\hline Virus level & & & 0.0001 & 0.1350 \\
\hline Nematode level & & & 0.2241 & 0.0001 \\
\hline Virus $\times$ nematode & & & 0.1609 & 0.0970 \\
\hline
\end{tabular}

${ }^{\mathrm{z}}(-)=$ not inoculated; $(+)=$ inoculated.

${ }^{y} 1=$ severe galling, more than $75 \%$ of roots galled, through $5=$ no galls.

javanicva (Treub) Chitwood infecting Cucurbita pepo L.. J. Nematol. 16:109-112.

Hussey, R.S. and K.R. Barker. 1973. A comparison of methods of collecting inocula of Meloidogyne spp., including a new technique. Plant Dis. Rptr. 57:1025-1028.

Jellis, G.J., C.N.D.Lacey, R.E. Boulton, S.B.Currell, A.M. Squire, and N.C. Starling. 1986. Earlygeneration screening of potato clones for disease and pest resistance. Aspects of Appl. Biol. 13:301-305.

Ogle, W.L., W. Witcher, and O.W. Barnett. 1987. Descriptors for the Southern Peas of South Carolina. South Carolina Agr. Expt. Sta. Bul. 659.

Ouattara, S. and O.L. Chambliss. 1991. Inheritance of resistance blackeye cowpea mosaic virus in 'White Acre-BVR' cowpea. HortScience 26:194-196.

Pio-Ribeiro, G., S.D. Wyatt, and C.W. Kuhn. 1978. Cowpea stunt: A disease caused by a synergistic interaction of two viruses. Phytopathology 68:1260-1265.

Showler, A.T., T.E. Reagan and K.P. Shao. 1990. Nematode interactions with weeds and sugarcane mosaic virus in Louisiana sugarcane. J. Nematol. 22:31-38.

Taylor, C.E. 1990. Nematode interactions with other plant pathogens. Ann. Appl. Biol. 116:405-416.

Walker, C.A., Jr. and O.L. Chambliss. 1981. Inheritance of resistance to blackeye cowpea mosaic virus in Vigna unguiculata (L.) Walp. J. Amer. Soc. Hort. Sci. 106:410-412.

Weischer, B. 1975. Further studies on the population development of Ditylenchus disaci and Aphelenchoides ritzemabosi in virus-infected and virus-free tobacco. Nematologica 21:213-218.

Weischer, B. 1993. Nematode-virus interactions, p. 217-231. In: M.W. Khan (ed.). Nematode interactions. Chapman \& Hall, New York. 